\title{
Kültürel Dil Bilim Bağlamında Kutadgu Bilig Metaforları
}

\section{The Metaphors of Kutadgu Bilig in the Context of Cultural Linguistics}

\begin{abstract}
Özge EKER * Abdullah KÖK **

$\ddot{O}_{z}:$ Bu çalışmada Kutadgu Bilig'deki kültürel metaforlar ele alınmıştır. Kültürel dil bilim ve bilişsel dil bilim bağlamında metafor konusu ve yöntemleri açıklanarak Kutadgu Bilig metninden hareketle örneklendirilmiştir. Kültürel dil bilimin çalışma alanını kültürel şema ve kültürel kategoriler yanında kültürel metaforlar oluşturmaktadır. Kültürel dil bilim bir toplumun kültürünün dilsel açıdan aktarımı üzerinde durur. Kültürel dil bilim kültürel metaforların bir toplumun yaşayış, algılayış, düşünce yapısını içerisinde barındırdığını bunun yanında bilişsel temellerinin olduğunu da savunur. Çalışmanın giriş̧ kısmından sonra kültürel dil bilimi ve metaforları hakkında tanım, açıklama ve yöntemleri hakkında bilgiler verilmiştir. Kültürel metaforların bilişsel bağlamda oluşumları (somutlaştırma, kapsayıcılık, yönelme) ve bunların kültürel bağlamda nasıl yorumlanabileceği örneklerle tartışılmıştır. Açıklamalardan sonra Kutadgu Bilig'de yer alan soyut kavram ve değerler, ölüm ve yaşam kavram alanı, sosyal yaşam, yönetim, şahıs adları ve hitaplar kavram alanlarına giren metaforik ifadeler sınırlı olarak bilişsel ve kültürel bağlamda açıklanmıştır. Sonuç kısmında ise açıklanan metaforlardan hareketle adı geçen kavramların bilişsel ve kültürel görünümleri kısaca açıklanmıştır. Kutadgu Bilig'de bilişsel açıdan yönelim, kapsam, yer alanları, varlık- madde, kişileştirme metaforları, kültürel açıdan ise tarihsel, dinî, kök metaforlar sistemli bir şekilde yer almaktadır. Çalışmanın sınırlılığı açısından burada sadece belli başlı kültürel metaforlara yer verilmiştir.
\end{abstract}

Anahtar sözcükkler: Kutadgu Bilig, Kültürel Dil Bilim, Bilişsel Dil Bilim, Kültürel Metafor

Abstract: This study concerns the cultural metaphors in Kutadgu Bilig. Metaphor topic and methods, within the context of cultural linguistic and cognitive linguistic, have been exemplified from the text of Kutadgu Bilig. The field of the study of cultural linguistic consist of cultural schemas and cultural categories as well as cultural metaphors. Cultural linguistic emphasises the transforming of society culture in terms of linguistics. Cultural linguistics supports the understanding that cultural metaphors contain the life of a society, perception and mentality also its cognitive basis. After the introduction this study provides information about cultural linguistic definition, explanation and methods. The creation of cultural metaphors in a cognitive context (embodied, container, orientation) and how they can be commented upon in their cultural context is discussed with examples. After these explanations, metaphoric expressions which include conceptual fields like abstract concepts and morals, death and life, social life, governing, people's names and addresses are explained in their cognitive and cultural context. In conclusion, those concepts which are based on metaphors which have been found and explained are employed to attempt to explain the cognitive and cultural view. In the Kutadgu Bilig there are two types of metaphors. One hand, the cognitive view orientation, content, land areas, object-matter and personalized metaphors, on the other hand the cultural view historical, religious and base metaphors. Because of the limitation of this study only some of main metaphors are emphasised.

Keywords: Kutadgu Bilig, Cultural Linguistics, Cognitive Linguistics, Cultural Metaphor

Ph.D., Akdeniz Üniversitesi, Sosyal Bilimler Enstitüsü, Türk Dili ve Edebiyatı Anabilim Dalı, Ankara. ozgeker@gmail.com, https://orcid.org/0000-0003-0977-8110

** Prof. Dr., Akdeniz Üniversitesi, Edebiyat Fakültesi, Türk Dili ve Edebiyatı Bölümü, Eski Türk Dili Anabilim Dal, Antalya. abdullahkok@akdeniz.edu.tr, https://orcid.org/0000-0002-3614-2719 


\section{Giriş}

Kutadgu Bilig Karahanlı döneminin kültürünü ve yaşayışını yansıtan, içinde bulunduran hem müstakil bir eserdir hem de bir kültürün mirasını devam ettiren değerli bir geçiş metnidir. Eser ayrıca mensup olduğu kültürün devamını sağlayan Tarihi Türk dili alanının önemli bir metnidir. Kutadgu Bilig'de bulunan kültür sözcükleri köklerini Türk kültür ve yaşantısından almaktadır. Kültürel, tarihi ve sosyal ifadelerin Kağanlık ve Uygur dönemlerinden sonra da aktarılması dil ve kültür bilincinin sonucudur. "İnsan kendisini, toplumu, kültürü dille tanır, yorumlar ve anlamaya çalışır" (Adalı 1982, 20). Yusuf Has Hacib yüksek bir kültür ve medeniyete sahip olduğunu bir dönem entelektüeli olarak biliyordu. Yeni tanıdıkları İslâm medeniyetinin kurallarını yeri geldikçe Türkçe aktarması, siyasî, sosyal, felsefî konularda Türkçeyi gelişmiş bir dil olarak kullanması onun dünya görüşü ve daha o dönemde bilgi birikiminin ne kadar yüksek olduğunu gösterir. Kutadgu Bilig'in içerisinde geçmiş- şimdi ve gelecek bağlamında konu çeşitliliğinin olması ve bu konuların Türkçeyle akıcı bir şekilde ifade edilmesi yazarının ve döneminin bilime, kültüre, eğitime, felsefeye, dine ve siyasete dair bilgi birikimlerinin ve söylemek istediklerinin var olduğunu göstermektedir. "Dil onu konuşanların duygu, düşünce ve hayal dünyalarını tayin eder. Bir dilde ne kadar kelime varsa o milletin dünya görüşü o kelimelerle sınırlıdir. Insanoğlu bildiği ve dikkat ettiği varlıklara, duygu ve düşüncelere ad koyar, bilmediklerinin o dilde adları da yoktur" (Kaplan 1983, 149). Kutadgu Bilig metnine bakıldığında metafor ifadelerinin sistemli bir şekilde yer aldığı görülür. Yusuf Has Hacib'in dil ve kültürü özümseyip kullanabilmesi yanında eserde metaforların bu kadar yoğun olması Türkçenin gelişmişliğini göstermesi yanında Türkçenin şaire/yazara tanıdığı imkanları da gösterir. Metaforlar dünya görüşünü ve dil mirasını tarih boyunca aktarabilme işlevine sahiptir. "Her dil dünyayı ve gerçeği insanın zihin süzgecinden geçirerek yansıtır. Dolayısıyla konuşurları ile farklı sahalarda olsa bile, genel Türk dili alanında da kendine özgü bir "dünyayı anlama ve anlatma yolu” vardır. Metaforlar da anlatım yolu ile ilgili olarak bir milletin dünya görüşünü yansıtması bakımından çok mühimdir" (Erdem 2007, 539).

Dil, söz ve toplum arasındaki bağlantı kültür dil bilim ve toplum dil bilim bağlamında incelenebilir. Kişinin topluma ait kültürden yola çıkarak kullandığı kültürün bireysel kullanımı söz olarak adlandırılır ve sözlerin kullanımı toplumsal kültür tarafından etkilenebilir. "Dil toplumla kültür arasında bağ kuran bir yapıdır. Toplumsal kültür, topluma ait kültür, Saussure'nin görüşündeki toplumsal olan dili belirtir. Kişinin bu topluma ait kültürden yola çıkarak kullandığı, yararlandığı kültür ise bireysel kullanımı olacaktır. $\mathrm{Bu}$ da söze denk düşecektir. Bu bireysel kullanımda toplumsal kültürün olanak verdiği ölçüde özgün kullanımlar ve özgünlükler olacaktır. Bunlar da toplumsal kültür çerçevesinde olacaktır” (Günay 2016, 19).

Dil, kültürü, kültürel ögeleri, düşünce ve değerleri tarihsel dil alanı içerisinde nesilden nesile aktarma işlevi görür. Ayrıca her dönemde gelişerek aktarma işlemini sürdürür. Dil, gelişme kabiliyeti olan bir unsur, tarihin, kültürün ve toplumların hafızaları olarak görülmüştür. "Bir toplumun (iletişim topluluğunun) dili iletişim ve bir diğer dilbilimsel pratiğin biraktığ izde yayılmış olan farklı aşamalardaki kültürel idrak elementleriyle gelişir. Bu açıdan dil önemli bir mekanizma olarak hafiza deposu ve kültürel idrakin depolama ve tekrar aktarım aracı olarak görülür" (Sharifian 2017, 5).

Kağanlık Yazıtlarında Türk yönetim sistemi ve düşüncesi sade fakat bir o kadar söylev niteliğinde aktarılırken, Uygur döneminde konu ve kavram alanı genişleyerek Türk toplumunun gelişimi, yaşantısı ve bilgi birikimleri farklı üslup ve bağlamlarda aktarılmıştır. Kutadgu Bilig'e baktığımızda ise bu gelişmelerin bir terkibini görürüz. Bunlara ulaşmamızı sağlayan en önemli araç dildir. Dil ve kültür arasında sürekli bir ilişki vardır. Bu sürekli ilişki içerisinde yer alan simge ve aktarmalar önemli bir işleve sahiptir. "Bir kültür, kazançlarını ayrı ayrı tekniklere naklettikçe genişler ve tek kalan dikkatler bir terkip mahiyetini alır. Dil bu terkibin en geniş 
aynasıdır" (Tanpınar 1977, 63). "Kültür tarihidir ve süreklidir. Ĕğer, kültür bir kuşaktan diğerine geçiyorsa, yani sürekliyse, onun her kültürde ortak nedenleri ve sonuçlart vardır. Her kültürün yaradılışa uzanan dolaylı bir geçmişinin olması yanında kültürlerin idealleştirilmiş değerleri vardır, onlarda sembolik, düşünsel işlev ve süreçlerin evrenselliğini gösteren benzerlikler de bulunması gerekir" (Güvenç 1995, 103-105). Aynı zamanda kültür ve tarih dile de yansır. Dil, kültür ve tarihi bütünüyle aktarabilme gücüne sahiptir. "Dünyaya gelen insanoğlu maddi ve manevi kavramlarl, kendi anadilinin kalıp ve değerleriyle algllamakta, içinde yer aldı̆̆ toplumun kültür ögelerini, dünya görüşünü, yaşam biçimini, inanç ve geleneklerini içeren kavramlarl diliyle edinmektedir" (Aksan 2015, 21).

Kutadgu Bilig'de yer alan binlerce yıllık kültür sözcükleri Türk kozmolojisine ve kültür tarihine işaret eder. Bu sözcükler Hun- Köktürk- Uygur siyasi, sosyal, kültürel düşünce ve tarih sürekliliği içerisinde bazen aynı bazen farklı biçimlerde bazen de aynı düşünce bağlamında Kutadgu Bilig'de yerlerini almıştır. Eserde yer alan metaforlu ifadelere bu anlayışla baktığımızda Türk düşünce sisteminin kaynaklarından ve Türk dünyasının ortak hafizasından gelen ortaklıklar görebilmekteyiz.

Kutadgu Bilig tarihi Türk dili alanının özellikli bir eseridir. Karahanlı kültürünün ve tarihinin de yansıtıldığ 1 bir eserdir. "Yazılı metinler cemiyetin kendini bilmek için sarf ettiği gayretin mahsulü olan ikinci derece eserler olmasının yanında (Tanpınar 1977, 91), herhangi bir kaynak olmaktan daha çok kültürel ürünlerdir ve bu kültür ürünleri de dilin belli bir yer ve anda donmuş şekillerdir" (Kaplan 1983, 189). "Kültür aynı zamanda yapma, farklılaşma olduğu kadar bütünleme, biçim verme, damgasını basma, üslup verme, yüksek bir üslup verme, mükemmelleştirme, geliştirme, derinleştirme demektir" (Kaplan 1983, 108). Bu sözlerden yola çıkarak Yusuf Has Hacib'in de Kutadgu Bilig'deki Türk kültürünü işleme anlayışını görebilmekteyiz. Köktürk ve Uygur kültür tarihi döneminden gelen birikimler ve kodlarla Kutadgu Bilig'i inşa etmiştir. Eserde Türkçe söz varlı̆̆ını felsefe, din, siyaset dili yapmasının yanında İslâm medeniyetinin esaslarını da yer yer Türkçe aktarabilmesi Yusuf Has Hacib'in kültürü işleme ve derinleștirme anlayıșından gelmektedir. Kültür çevresinin temelinin semantik ve kültürel olarak ortaya çıkarılabilmesi mitolojinin öğrenilmesine de bağlıdır (Bayat 2015, 24) "bu düzenin topluma nasıl yansıdığ hakkındaki görüşler milli psikolojiyi anlamaya” bağlıdır (Bayat 2015, 61).

Eldeki çalışmada da zaman zaman bilişsel anlam biliminden yola çıkarak metaforların kültürel bağlamda yorumlandığında sürecin antropoloji ve sosyolojiye doğru giderek metaforlar aracılığı ile sosyal ve siyasi kültürün, mitolojinin ve tarihin yeniden yapılandırılmasının kültür dil bilim ve gösterge bilim süreçlerine doğru geçtiği görülmüştür.

\section{Kültürel Dil Bilim}

Kültürel dil bilim ve bu bağlamda metafor çalışmaları takip edebildiğimiz kadarıyla White (1982), Croft (1993), Palmer (1996), Holland \& Quinn (1989), Sweetser (1995), Kövecses (2005; 2009; 2017), Sharifian $(2001 ; 2012 ; 2015 ; 2017)$ tarafından yapılmıştır. Türkiye'de de dil ve kültür arasındaki ilişkinin önemiyle ilgili çalışmalar yapılmıştır. Dil - kültür arasındaki ilişki ve bilişsel dil bilim ve kültür bağlamında tarihî metinleri yorumlama çalışmalarının başl1caları şu şekildedir: Tanpınar (1977), Üçok (1947), Tansel (1978), Kayabilgegil (1984), Kaplan (1982), Aksan (1978; 1990; 1998), Akarsu (1984), Erdem (2003), Yunusoğlu (2003), ÜstünelYaylagül $(2015 ; 2016)$.

Dil ve kültürün sosyal bağlamda aktarılmasının temelini ilk olarak Humboldt'a dayand1rabiliriz. Franz Boas, Edward Saphir, Benjamin Whorf ve dil bilim okullariyla birlikte bu anlayış geliştirilmeye çalışılmıştır. "Kültürel dil bilimin temelleri XX. yüzyıldan çok daha önce W. Humboldt tarafindan atılmış̧ır. W. Humboldt milli ruhun ve dünya bakışının dile yansıdiğııı ifade etmiştir (Kozan 2014, 11). Wilhelm von Humboldt (1767- 1835), Franz Boas (1858-1942), Edward Saphir (1884-1939) ve Benjamin Whorf (1897-1941) dil-düşünce ve kültür arasindaki 
ilişkiyi her zaman vurgulayan önemli araştırmacılardır" (Sharifian 2015, 1-2; 2017, 113-117). Fakat dil ve kültür arasındaki ilişkiye tamamen odaklanan özelleştirilmiş bir alt disiplin gelişmemiştir. Bu gelişmeler daha çok XX. yüzyıl sonunda oluşmaya başlamıştır.

Metafor ve kültür çalışmalarının yakından ilişkili olduğu göz önüne alındığında, kültür esas olarak dünyayı paylaşan bir dizi anlayış olarak görülmektedir (Kövecses 2005, 283). Dil olgusunun temelinde bilişsellik vardır. Bunun da üzerinde dil kavramlarının göstergesi olan metaforların kültürel kökleri vardır ve sosyo-kültürel pek çok alana hizmet edebilir. Kövecses, yaptığ1 açıklamalarla tarihsel, kültürel ve kök metaforların tanımlarını da yapmasının yanında metafor çeşitliliğini dünyadaki kültür ve toplumların çeşitliliğine bağlamıştır. Kültürel metaforlarda kaynak alanın hedef alandan daha somut ve gerçekçi olması gerektiği görüşündedir. "Dil kavramsal metaforların temel göstergesi olmasının yanında belirli Whorfian etkiler de yaratabilir. Konuştuğumuz dilin kavramsal metaforların bilmek soyut kavramlar hakkinda düşünme biçimimizi etkileyebilir. Kavramsal metaforlar genellikle dilde ifade edilir ve kültürün temel bir bileşenidir. Kurumlar, davranışlar, semboller ve eserler de dahil olmak üzere kültürel pratikte kavramsal metaforlar gerçekleştirilebilir. Kültürler, pratikte hangi metaforların gerçekleştirileceği veya belirli metaforların gerçekleştirilme derecesi bakımından değişebilir. Kavramsal metaforlar kültürel olarak farkl sosyal kültürel işlevlere hizmet edebilirler. Kültürler kismen dünyadaki paylaşılan metaforik anlayışlar olarak görülebilir. Kültürlerin paylaşllan anlayışlar kümesi olarak düşünülebileceği düşünüldüğ̈̈nde, figüratif düşüncedeki yaratıcılık (metaforlar dahil) kültürlere değişim ve yeni deneyim potansiyeli sağlayabilir" (Kövecses 2005, 284).

Kültürel dil bilim terimi, dil özellikleri ve çeşitlilikleri yoluyla temsil edilen kültürel şekilde yapılanmış dil ve kavramlaştırma arasındaki ilişkiyi araştıran disiplinler arası araştırma alanı için kullanılmaktadır (Sharifian 2015, 2). "Diğer adı ethnolinguistics olan kültür dil bilimi kültürel kavramlaştırmaları kodlayan veya örnekleyen ve bir dizi insan yaşantılarının tamamını içeren/ karşılayan insan dilinin özelliklerine bağlıdır. Bir başka deyişle bu insan dilinin pek çok özelliği kültürel kavramlaştırmada yerleşik veya gömülüdür” (Sharifian 2017, 1-2). "XX. yüzyılın doksanl yıllarında ortaya çıkan kültürel dil bilimin araştırma alanı; kültürel bilgilerin aktarıcısı olan dilin, yapılarıyla ve kurallarıyla kültürün ve dili kullanarak bu kültürü yaratan insanın etkileşiminin incelenmesidir. Bu bilimsel disiplinin görevi dil ve kültür, dil ve budun, dil ve halk mantalitesinin etkileşimini incelemek ve açılklamaktır" (Amirova \& Dohman 2014, 2425). "Dil bilimsel etnografi gibi kültürel dil bilim kendi sosyo kültürel zeminine bağll olan dilin bağlamını araştırır. Kültürel dil bilimin bakış açısı, kültürel kavramlaştırma çalışması türü olan dilin sosyo-kültürel zemini araştırmaları anlam yapımı için dil kullanımının altını çizer" (Sharifian 2017, 41).

"Ayrıca, Kültürel dil bilimin araştırma alanı, dil bilim, kültür bilim, budun bilim, ruh dil bilim gibi birkaç temel bilimin kesiştiği noktada yerini almaktadır" (Amirova \& Dohman 2014, 24). Bu disiplinlere ek olarak kültürel dil bilimi teorik temellerini geliştirebilmek adına bilişsel psikolojiyi ve antropolojiyi içeren pek çok disiplin ve alt disiplinlerle de ilgilidir (Sharifian 2017, 2).

Geleneksel dilbilime göre Kültür dil bilimin amacı daha çok dilsel kavramların taşıyıcısı olan metaforların toplum hafızası ve tarihinin aktarılması sürecini izlemektir. Aynı şekilde kültürel dil bilim de bu işlevlerin nasıl gerçekleştiğini disiplinler arası yöntemlerle çözmeye çalışır. Dil kültürel ve sosyal unsurları aktaran bir varlık olmasının yanında dilde tarih boyunca yaşayan her şey kültür unsurudur. Bu açıdan bakıldığında dil ve kültür sosyal ve kültürel bağlamda olduğu gibi bilişsel bağlamda da birbirlerini tamamlarlar.

"Çağdaş bilişsel bilim ve dil bilimin birçok etkili eğiliminde, soyut düşüncenin, insanın yaşadiğ somut tecrübe alanlarına dayandiğg düşünülmektedir" (Kövecses 2005, 284). İdrak anlam bilimi kültürden ayrı düşünülemez ve bu çerçevede metaforlar da idrak anlam biliminin 
en önemli konuları arasındadır (Erdem 2003, 4). "Kültürel dil bilimin teorik çalışma alanının merkezinde, ilgili olduğu dilin kavramlarını kültür ve bilişsellik bağlamında anlamak için bir bütünleştirmeye ihtiyaç duyan kültürel bilişsellik vardır" (Sharifian 2015, 2; 2017, 1-3).

Sharifian, kültürel metaforlar yanında kültürel ve bilişsel dil bilimde araştırma teknikleri olarak kültürel şema ve kültürel kategoriyi sunar. "Kültürel dil bilim insan dilinin kullanımının altını çizen kültürel kavramlaştırmayı araştırmak için belirli kültürel kavramlaştırma örnekleri olan teorik ve analitik çalışma alanına sahiptir. Kültürel şema, kültürel kategoriler ve kültürel metaforlar teorik çalışma alanı gösterimleridir. Bunlar aynı zamanda kültürel dil bilimin analitik çalışma alanlarıdır”. Sharifian, daha sonraki çalışmalarında ise kültür dil bilimin teorik çalışma alanını kültürel idrak, kültürel kavramlaştırmalar ve dil; kültürel dil bilimin analitik çalışma alanını ise dil ve kültürel kavramlaştırmalar arasındaki ilişkiyi analiz etmeye sağlayacak özellikleri test etmemizi sağlayan araçlar olan kültürel şema, kültürel kategori ve kültürel metafor kavramlarının oluşturduğunu (Sharifian 2001, 1-2; 2012, 97; 2017, 7) belirtir. "Kültürel şemalar, kültürel kategoriler ve kültürel metaforlar kültürel kavramlaştırmaların ve bu kültürel kavramlaştırmanın dildeki hendekleri üzerinde çalışan kültürel dil bilimin üç analitik aracıdır" (Sharifian 2017, 23). "Tarihi-kültürel yaşantılar şu anki dil bilimsel unsurlarına fosilleşmiş ve artık analiz edilemeyen izler bırakırlar. Bu açıdan dil, kültürel bilişin aktarımı ve depolama aracı olarak görülür. Diğer bir deyişle dil, hafiza bankası ve kültürel bilişin tekrardan aktarımı için aklşkan bir araç ve bu kültürel şema/ kültürel kategori (kültürel prototip)/ kültürel metaforlar olan kültürel kavramlaştırmaları oluşturan bir unsur olarak görülür" (Sharifian 2012, 97).

\section{Kültürel Dil Bilim ve Metafor}

Sosyal kültürel deneyim ve bilişsel süreçler ile metaforlar arasında tutarlılık üzerinde duran Kövecses figüratif anlayışın kültürdeki rolü üzerinde durmuştur. "Dünyaya dair anlayışımız hem somut hem de soyut nesneleri ve olaylart içerdiğinden, doğal olarak figüratif düşünce, soyut nesneler ve olaylar durumunda bir rol oynamalddir. Kavramsal metaforlar genellikle belirli bir kültürde güçlü bir fiziksel malzeme varlı̆̆ına sahiptir” (Kövecses 2005, 283-284).

"Metaforları kullanan konuşurların zihninde, toplumdaki değeriyle mevcut olan öyle kavramlar vardır ki bunlarla ilgili metaforların iyi anlaşılabilmesi için o kavramın sosyo kültürel değerlerinin de bilinmesi gerekir" (Erdem 2007, 545). Bilişsel dil bilim çalışmalarında metaforlar ifade edilirken onların sosyo-kültürel, psikolojik bağlamda açıklanması da gerekir. Ayrıca metaforu oluşturan alanlar içerik ve kökenlerini içinde oluştukları kültürel ve toplumsal değerlerden alırlar (Erdem 2003, 3).

"Metafor vasitastyla nüfuz sahaları arasında etkileşime sebebiyet veren kavramlar, insan zihninde o toplumun kültürüne ve değer yargllarına göre de şekillenebilmekte ve değer kazanabilmektedir. Buna göre toplumdaki kültürel imaj ile de sıkı bağlantılı olan kavramın, ortak dünya görüşüne sahip topluluklar içinde, o toplumun maddi ve manevi değerleriyle fertlerin muhayyilesinde yer aldiğı bir gerçektir. Metaforlar da zihni imajlara bağlı olmanın yanı sıra aynı zamanda kavramın birtakım zihni imajlarla bir nüfuz sahasını oluşturan sosyal değeridir" (Erdem 2007, 542-543).

Düşünce yapısını ortaya çıkarabilmek için aslında metaforik ve bunun yanında metafor oluşumunda işlevi olan metonimik yapıların da incelenmesi gerekir. Metaforların oluşumunda ve yorumlanmasında coğrafi özellikler dahi etkili olabilir. "Türk toplumunun düşünce yapısı ve bilişsel yapısının incelenmesi, bilişsel yapısı ile kavramsal sistemin ilişkisi, bununla ilgili olarak metaforik, metonimik $v b$. anlatım yollarının ele alınip incelenmesi sonucu aydinlanabilir" (Yunusoğlu 2016, 36).

Metaforlar farklı disiplin çalışmalarında örneğin söylem çalışmalarında da sosyal ve kültürel 
kökleri ile ele alınmaktadır. Metni çok sesli yapan, zenginleştiren kolektif simge, tarihin ve kültürün yeniden aktarıcıları olarak görülür. "Ayrıca bu metaforlar bir kültürde geçerli olan imgelerin, deyimlerin, atasözlerinin, ĕgretilemelerin hatta örneklendirmelerin tümü olan kolektif simgeler olarak kabul edilmektedir. Aktartm yoluyla gelenekselleștirilen ve kullanılan kültür kalıpları olarak görülür. Birey- söylem ilişkisi bağlamında, söylemleri bireyler oluşturuyor gibi görünse de özünde söylemler tarihsel ve sosyal-politik süreçlerin sonucu olarak belirginleşirler ve birey üstü söz düzenidirler" (Kula 2012, 150).

Kültürel kavramlaştırmalar, insan yaşantısının diğer pek çok yönünü kültürel sanat, edebiyat, kültürel olaylar, halk şarkıları, ritüeller, sözsüz davranışlar ve duyguları da örneklendirir ve bu alanlarda da metaforların işlevleri bulunmaktadır (Sharifian 2017, 6). Metaforlar kültürel kategori oluşturmada, kavramlar arası ilişkileri kurmada kavramsal kriterlerden biri olarak görülür. "Metaforlar birbirleriyle farkl alanlardan iki ayrı olay veya varlığın birbirleriyle ilişskilendirme sürecinde oluşur" (Sharifian 2001, 3). Sharifian önceden kullandığı kültürel metaforları sonraki çalışmalarında kültürel-kavramsal metaforlar olarak adlandırmıştır. "Bilişsel dil bilimin başlıca analitik aracı kavramsal metaforlardır. Kavramsal metafor kavramı kültürel dilbilimin merkezi konumundadır. Bu açıdan kültürel dil bilim kavramsal metaforların kültürel temelleri üzerine odaklanır. Bilisssel dil bilimde kavramsal metafor olarak tanımlanan yapılar kültürel dil bilimde tekrardan gözden geçirilir. Bu açıdan bakıldığında kavramsal metaforların bazılarında konuşmacı tarafindan bir kaynaktan diğerine herhangi bir haritalamadan ziyade din ve dünya görüşü gibi kültürel düşünce sistemleri yerleşiktir. Burada düşünce çerçevesinin çıkardı̆̆ı kavramsallaştırmalar önemlidir. Temel kavramsallaştırma bir düşünce çerçevesi çizer ve bu kavramsallaştırma konuşmada veya bir alandan diğerine bilinçli yaratıcı bir haritalama olmasından ziyade konuşulanların ve dil çeşitliğinin gerçek olduğunu gösterir”" (Sharifian 2015, 10).

Kültürel dil bilimde teorik ve analitik çalışma alanları olmak üzere iki alan gösterilmektedir. Çalışmaya konu olan kültürel metaforlar kültürel dil bilim içerisinde analitik çalışma alanı içerisinde yer almaktadır ve bir kültürel kavramlaştırma örneğidir. "Kültürel metaforların temelinde de kavramları kültür ve bilişsellik bağlamında yorumlama ihtiyacı duyan kültürel bilişsellik vardır" (Sharifian 2017, 1-3).

"Kültürel metaforlar etki alanlarının kavramlaştırmalarl, dünya görüşü ve manevi inanış sistemlerine bă̆lıdır. Kültürel dil bilimin analitik çalışma alanı dilin seviyesini ve morfosentaktik özelliklerden pragmatik semantik anlam ve bağlamlara kadar giden özelliklerin nasıl tarif edildiğini gösterir ve bu özellikler kültürel şema, kültürel kategori ve kültürel metaforlar olan kültürel kavramlaştırmalarda yerleşik olabilir" (Sharifian 2017, 7).

Kültürel metaforlar yazarın/kişinin dünya görüşüne ve kültürel kavramsallaştırmalarına bağlıdır. Holland \& Quinn (1989) ve Erdem'in (2003) de belirttiği gibi etki alanları haritalamasının sonucu olan kavramsallaştırmalar ve kültürel metaforlar konuşmacının/yazarın alanlar arası kavramsallaştırma derecesi hakkında bilinçli olup olmadıklarına bağlı olduğu belirtilmiştir (Sharifian 2017, 23). Kültürel metaforların temelinde kültürel kavramlaştırmalar olduğu için metaforun yorumlanma ve kültür dil bilimin çalışma alanları içerisinde kültürel kavramlaştırmalar önemli bir yerdedir (bk. Holland \& Quinn 1989, 30; Erdem 2003; Sharifian 2017).

"Toplumun (iletişim topluluğunun) üyelerinin, kişinin gözlem ve dikkatlerine bağlı iletişim süreçleriyle ilgili olan, onların kavramsal ilişkilerinin diğer dilsel özellikleriyle ilgili olup olmama durumlarının, dil üzerine odaklanabilen ölüm/yaşam gibi deneyim alanlarının, önemli bir duygu, sıcaklık, kızgınlık gibi belirli bir duyguyla ilgili kültürel ve dil kavramlaștırmalarının araştırılması, belirli bir alandaki anahtar kavram ve sözcügüüün tanımlanması kültürel dilbilimdeki yöntemlerdendir. Örneğin politikadaki esas terim olarak demokrasi kavramının tarihsel ve kültürel kökleri verilen çevrede bulunan özel gelenekler içinde araştırllabilir. Analiz temelli yoğun bir betimlemenin yanı sıra kültürel dil bilim bağlamında, iletişim sürecindeki üyeler 
tarafindan yaşantıların kültürel olarak yapılandırılmış kavramsallaştırmaların etnografik analizi olabilir" (Sharifian 2017, 41-42).

Kültürel dil bilimde kullanılan araştırma metotları kavramsal ilişkisel analiz, hikâye anlatımlarındaki kavramsal analiz, meta söylem analizi, korpus tabanlı araştırma, etnografik kavramsal metin veya görsel analizi, diakronik-senkronik kavramsal analiz (Sharifian 2017, 42-50) olarak sinıflandırılmaktadır.

"Diğer yandan kültürel dil bilimin kullanıldı̆̆ disiplinler ise, etnosemantik, linguaculture, dil, cinsiyet ve kültür ilişkisi, dil, kültür ve bağlam, kültürel semiyotik, dil, kültür ve aktarım, dil, kültür, kimlik, dil ve kültür tarihi, dil, kültür ve mekânsal biliş, kültürel ve dilbilimsel zaman ve uzay kavramı, kültür ve dil edinimi, dil ve kültürel iletişimler veya dilde kodlanmış olan kültürel normların temsili, sosyolingüsitik alanda kültür araştırmaları, bilişsel antropoloji, dil ve kültür araştırmalart, yabancl dil edinimi ve ögrenimi, ikinci lehçe ögreniminde dil ve kültür araştırmalarıdır" (Sharifian 2017, 123-149).

\section{Kültürrel Metaforlar}

Kaynak ve hedef alan seçimlerinin üzerinde durulduğu kültürel metaforların temeli kavramsaldır. Kavramsal metaforların temelinde ise çoğunlukla somutlaştırma yer almaktadır. Tarihî Türk dili metinleri içerisinde de somutlaştırma yoluyla yapılmış metaforlara sıkça rastlanmaktadır. $\mathrm{Bu}$ durum aynı zamanda "Türk düşünce sisteminin dünya modelini kavramada bilinenden bilinmeyene, görülürden görülmeyene, somuttan soyuta geçiş düşüncesine" hizmet etmektedir (Bayat 2015, 29). Kaynak alan ve hedef alan arasında kurulması gereken ontolojik (varlık), epistemolojik (bilgi), psikolojik ortaklıklar yine Türk düşünce sisteminde dünyanın ne ölçüde nasıl algılandığını da göstermektedir.

"Bilişsel dil bilimde kavramlaştırma türü kavramsal haritalama veya kavramsal metafor olarak adlandırllır. Kavramsal metafor teorisi olarak bilinen bilişsel dil bilimin alt paradigmalarl kavramsal metafor çalışmalarıdır. Kültürel şema ve kültürel kategorilerin aksine fakat çoğunlukla kavramsal metaforlara benzeyen kültürel metaforlar kaynak ve hedef alan olarak bilinen farklı alanların kavramsallaştırılmasını içerir. Teknik açıdan kültürel (kavramsal) metaforlar etki alanlarının kavramlaştırmasının bir formudur. Kültürel dil bilime göre kültürel metaforlar kültürel kavramlaştırmalardır ve bunların birçoğu köklerini yerel yaşantılar, tarihi ve dini görüş açılarından almaktadır" (Sharifian 2017, 18).

Örneğin doğal olaylarda çiçeklerin açması, renklerin değişmesi şeklinde doğal olaylar aracılığıyla insanlara verdikleri sinyallerle toprağın karakterizasyonları TOPRAK YAKIN BİR ANNEDİR- BABADIR kültürel metaforuyla bağlantılıdır (Sharifian 2017, 19). "Bu tür kültürel metaforlar yazarın ya da kişilerin dünya görüşlerini somutlaştırırlar, kavramlaştırırlar. Aynı zamanda bu yapılar kültürel deneyimleri sinıflandırırlar ve bilişsel bir çerçeve çizerler. Bunlar kişilerin dünyasının kültürel şemasının bir parçasıdır" (Sharifian 2017, 21-22).

Deyim aktarmalarının birçok oluşum yolu vardır. "Bunlardan açık istiare adı verilen doğa unsurlarının insanlara aktarılmast ve deyimlerin oluşum yollarından biri olan somutlaştırmadır. Diğer bir deyim aktarmasinin da soyut, anlatılması güç düşünce ve duyguların, soyut kavramların somut kavramlar aracılığ ile yapılması anlamına gelen somutlaştırma yollarıyla oluştuğunu ifade etmiştir" (Aksan 1990, 186-187). Aksan'a göre deyim aktarmasının diğer oluşum yolları ise şunlardır; "Somuta yeni somut anlam eklenmesi; Somuta yeni soyut anlam eklenmesi; Soyuta yeni soyut anlam eklenmesi; Soyuta yeni somut anlam eklenmesi yollarıdır"(Aksan 1990, 188). Bilişsel bağlamda "renk, temel kavramlar, mekânsal ilişkiler ve görünüş kavramlarl gibi kavram türlerinin şekillendirilmesinde algisal ve motor sistemler önemli bir rol oynamaktadır" (Lakoff \& Johnson 1999, 16). "Somutlaştırma veya cisimleştirme düşüncesi bilişsel dil bilimin geleneksel dil bilimden doğan tarafidır" (Kövecses 2009, XII). Somutlaştırmanın zorluğu düşüncenin çok farklı yollarıyla 
oluşturulmasına bağlanmaktadır (Kövecses 2009, 116). Container schema (içerik alanı) ve force schema (etki alanı) adlı iki imaj şemanın duygusal kavramların kavramsallaştırılmasında önemli rolleri bulunmaktadır.

"İ̧̧erik alanına duygularla ilgili temel düşünceler yerleştirilir. Şöyle ki; duygular veya olaylar/durumlar yani taşlyıcı durumundaki insan vücudunun içerisinde olan duygular ve olaylar. Ikincisi ise, belirli nedenlerle üretilmiş duygular ve meydana gelen sonuçlar veya karşılıklarladır. Kişinin duygusu özel bir karşılığa denk gelir. Etki şeması, etki alanı bir diğer güçlü kavramla etkileşime giren bir başka güçlü kavrama, fikire ve görüşe bağlldır. Buradaki olay sadece, iki güçlü duygunun/kavramın/düşüncenin bir araya gelip etkileşmesidir. Bu iki alan da duyguları kavramsallaştırmada önemli rolü olan fiziksel deneyimlere bağlıdır" (Kövecses 2009, 117).

"Kövecses'e göre duygusal kavramlart metafor ve metonimi şekillendirir ve somutlaştırır. Böylelikle dil ve düşünce de yapılandırllır. Somutlaştırmanın temelinde öncelikle bilişsel bir algl vardır. Somutlaştırmanın kullanıldı̆̆ bă̆lam veya aktardlğg içerik de onun kültürel köklerinin olup olmadığını gösterir. İnsan bedeninin rolün kavramlaştırma konusu üzerinde bilişsel bilimlerle çalışma konusu olmuştur. Kültürel dil bilim somutlaştırılmış kültürel metaforları inceleme yoluyla dili şekillendiren kültürel kavramlaştırmaların rolü üzerinde odaklanmıştır" (Sharifian 2017, 26).

Casasantos soyut kavramlar ve zihinsel simgeler arasındaki somutlaştırma hipotezini "sahip olduğumuz vücut organlart soyut kavramlart simgeleştirmemizde önemli bir rol oynuyorsa o halde farklı organlar farkl soyut kavramları niteler" şeklinde tanımlamıştır. Casasonta "pozitif değerler sağdır" "negatif değerler soldur" demekle mental/ zihinsel metaforları kast etmiştir.

"Bilişsel dil bilimciler de bunu kavramsal metaforlara denk gelen "doğru sağdır" "kötü soldur" şeklinde ifade ederler. İngilizcedeki "O benim să̆ kolumdur" söz diziminde olduğu gibi bu metaforların evrensel olduğunu göstermektedir. Cassasonta bunun muhtemelen iyi şeylerin evrenselliği, sağlak insanların dünyadaki çokluğu ile beraber bu insanların tavırları ve davranışları (hareketleri) solu kullananlara göre daha akıcıdır şeklinde açıklamıştır" (Kövecses 2009, 118).

Kavramsal metaforların temelinde somutlaştırma vardır. Somutlaştırma kültür dil bilim için önemli konulardan biridir. Çünkü kaynak alan hakkında ne kadar bilgiye sahipsek metaforun oluştuğu kültürel ortam da o kadar iyi bilinir. Kövecses, Sharifian, Ervas \& Gola kaynak alanın niteliğinin kültürel metaforlar için önemli olduğu vurgusunu yapar. "Soyut kavramlar vücut organları ile özel bir yolla kavramsallaştırılır. Duygu kavram yapıları böylece "kavramsal metaforlar", "kavramsal metonimiler", "bilişsel/kültürel" modeller olarak tanımlanabilmektedir. Bu bilişsel/kültürel modeller kavramlartn bilişsel simgeleri olarak görülmektedir (Kövecses 2009, 119). Doğrudan gerçek dünyayla alakall olan birincil metaforlarda kaynak alan somutlaştırma ve yaşantıların anahtar kavramlarında yoğunlaşabilen parametrelerden seçilir" (Ervas \& Gola 2013, 23).

Kapsayıc1 metaforlar "kelimelerin temel anlamlarında olup da gramatikal kategorilerinin değişerek yalın, kalma veya belirtme halinde oluşlarına göre değişik anlamlar ifade eder" Türkmen Türkçesinde "nesne olan kavramlar, yerine göre içinde bir şeyleri barındıran kapsayıcı bir yer de olabilirler" (Erdem 2003, 246). Soyut kavramların yer- alan olarak algılandığ metaforlar taşıyıc1- kapsayıcı metaforlar olarak da adlandırılır. "Örneğin, "başarıya ulaş-" ifadesinde soyut kavram başarı yer olarak algılanmıştır ve taşıyıcı durumdadır” (Yunusoğlu 2016, 73).

"Hisleri, bilinci, sağlı̆̆l ve çeşitli diğer alanları düzenleyen yukart- aşağı, ileri- geri, iç-dlş̧ gibi boşlukta yönelme hissi yönelmeli metaforları oluşturmaktadır" (Lakoff \& Johnson 1980, 14) (Erdem 2003, 175). Yönelim metaforları temel fiziksel ve kültürel deneyimlere bağlı olarak 
meydana gelmektedir (Lakoff \& Johnson 1980, 14).

\section{Kutadgu Bilig'de Kültürel Metaforlar}

Kutadgu Bilig'de yer alan metaforların temeli kavramsal metafor tekniğine dayanır. Her metafor temelinde kavramsallaştırmaya ve aslında somutlaştırmaya dayanır. Kaynak alan olarak doğa, insan bedeni, somut nesneler, eşyalar ve temel bilişsel eylemler seçilmiştir. Temel söz varlı̆̆ şahıs ve yer adları, aktarılmak istenen düşüncenin işlendiği hitap ve unvanlar, miktar ifadeleri, duygu ve değer ifadelerinin aktarımı kültürel metaforların yansıtıldığı bağlamlardır.

Bilişsel ve yapısal dil bilimin yanı sıra kültürel dil bilimin de konusu olan metaforlar Kutadgu Bilig'de saptanmaktadır. Bilişsel dil bilimde bahsedebileceğimiz varlık- ontolojik metaforlar, yönelmeli metaforlar, yer alanları, uzam, kanal metaforlar gibi ifadelerde aynı zamanda kültürel temelleri de görebilmekteyiz. Temel söz varlığı, kültürel sözcüklerle yapılan metaforlar yanında dönemim tarihi ve bakış açısını yansıtan metaforlara da rastlanmaktadır.

Tarihî Türk dilinin özellikli kültür sözcüklerinde köyül soyut kavramı ile ilgili yer alan metaforlar eserde kaynak alanları madde, kapsayıcılık, taşınan nesne şeklinde bilişsel olarak görülebilmektedir. Köyül soyut sözcügünün oluşturduğu bu metaforik ifadelerden bazıları günümüze kadar gelmiştir. Bu nedenle bu metaforlar kültürel metaforlar olarak adlandırılmaktadır. Ayrıca könül sözcügünün başka dillerde tam olarak karşılanamaması da bu düşünceyi güçlendirmektedir. Örneğin könül ba- (46), könlügi artat- (1082), könül bir- (1172), könli s1-

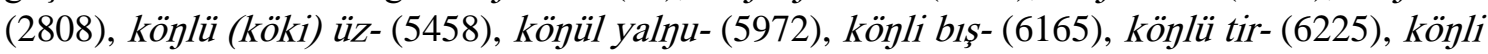
yuwka (4610) ifadesinde ba- eylemi köyül sözcügünü madde yönünde somutlaştırarak metaforik bir ifade oluşturmuştur. Bu metaforun kaynak alanı somut bir maddedir. Hedef alanı ise könül sözcügüdür. Könülke al- (782) ifadesinde ise gönül bir kapsayıcı görevindedir. Hatırında tutmak anlamında olan metaforik ifadede kaynak alan mekandır. Hedef alan ise soyut könül kavramıdır. Hatırda tutulması gereken sözler ve nasihatler için köyül kapsayıcı durumundadır. Könli köni tut- (3139), könlü tüz kıl- (3148) ifadelerinde ise könül taşınan nesne durumundadır. Gönlü doğru ve dürüst bir şekilde korumak eylemi sözcüğü taşınan nesne/madde şeklinde metaforlaştırmıştır. Könülke biti- (1341), könülke tokı- (2253) ifadelerinde ise biti- (yazmak) ve tok1ifadeleri könül sözcügüne somut bir alan anlamı yükleyerek metaforik ifade haline getirmiştir. Kaynak Alan mekan/alan olmak üzere hedef alan ise köyül soyut kavramıdır. Könül agrritur (4302) ifadesinde ağr1- oluş eylemi gönül soyut kavramını bir insan uzvu niteliğinde somutlaştırarak ontolojik bir metafor bağlamında üzüntülü olma durumunu karşılamıştır. kögli king (4416) ifadesinde ise genişlik ölçü kavramı gönül soyut kavramını alan/mekan olarak metaforlaştırmıştır ve bir yer alan metaforu meydana getirmiş̧ir Kọ̈lün eşit (359), kọ̈ül tut- (1167, 1656) ifadelerinde ise gönül metaforik olarak kulak işlevi görür. Gönlünle, kalbinle dinle veya can kulağı ile dinlemek anlamları için gönül sözcüğü somutlaştırma yoluna gidilerek kulak işlevini karşılamaktadır. Köllü awnur (2694), könli balıg (5430) ifadelerinde ise avun- ve yaralı ifadeleri gönül soyut kavramını kişileştirmiştir. Kaynak alanı insan ve hedef alanı gönül olan köylü awun- ifadesi yetinmek, köylü balıg ifadesi de çok üzülmüş anlamlarını tarihi Türk dili alanı boyunca gelmektedir. Kögül yilküt- (3104) ifadesinde ise metinde ferahlamak anlamına gelen yilküt- eylemi gönül soyut kavramını hem kişileştirmiştir hem de mekân bağlamında metaforlaştırmıştır. Kaynak alanı insan ve mekân olan ifadenin hedef alanı gönül sözcügüdür. Könlü kara bol- (6463), könül til ala bol- (6579) ifadelerinde ise tarihî Türk dili alanının sözcüklerinde kara ve ala renkleri köyül sözcügünü yoldan çıkmak ve yabancılaşma bağlamında metaforlaştırmıştır. Gönlün kararması ve alacalanması gönül sözcüğünü taşınan nesne olarak metaforlaştırmıştır. Burada renkler kapsayıcı durumdadır. Gönül sözcüğünden sonra Kutadgu Bilig'de tek kullanım olan yürek sözcüğü yüreki ul- (6139) yüreği parçalanmak şeklinde görülmektedir. Ul- bugünkü Türkiye Türkçesinde çürümek, yok olmak anlamında da kullanılmıştır. Gerçekte yüreği/ kalbin parçalanması ölüm nedenidir. Burada da yüreğin parçalanması 
çok üzülmek, acı çekmek anlamındadır. Ul- eylemi yürek soyut sözcügüunü somutlaştırarak varlık- madde metaforu oluşturmuştur. Yüreği parçalan-, yürek parçala- ifadeleri bugün de dilimizde kullanılmaktadır. Ayrıca bugün kalbi, gönlü parçalandı demiyoruz ve ul- eylemi için o gün de yürek sözcüğünün kullanılması sistemli bir süreklilik ve kültürel kodun göstergesidir. Köyül til törütti köni söz için (1024) ifadesinde doğru söz için gönül ve dilin yaratılması köni söz/doğru söz ifadesini taşınan nesne/madde olarak metaforlaştırır. Gönül ve dil ise doğru sözler için kapsayıcı durumundadır. Könline sığdı (memnun kal- 1607) ifadesinde de gönül soyut kavramı memnuniyet kavramı için kapsayıcı durumundadır. Aynı zamanda gönül bu duygular için somut bir yer oluşturarak yer- alan metaforunu meydana getirmiştir.

Burada görüldüğü gibi metaforlar kavramsaldır ve tüm metaforların temelinde somutlaştırma vardır. Ayrıca kavramsal metaforlar aynı zamanda kültürel metaforlardır. Denilebilir ki Tarihi Türk dili alanında ve Türkiye Türkçesinde olumlu ve olumsuz anlamda bağl1lık, üzüntü, kendini geliştirmek, güçlü olmak, merhamet, hatırlamak, hatırda/akılda tutmak, unutmamak, cömertlik, mutluluk, şaşkınlık, gerçek bağlamda işitmek gönül sözcüğünde toplanmıştır, gönül sözcügünde kavramlaştırılmıştır.

Kutadgu Bilig'de yer alan metaforlar içerisinde de insan bedeni ile yapılmış kavramsallaştırmalar da sistemli şekilde yer almaktadır. Soyut değer ve kavramlar için insan bedenine ait parçaların kullanıldığ 1 görülür. Örneğin eli kin (6488) ifadesinde genişlik yön kavramı cömertlik olarak metaforlaştırmıştır. elgi akı (2073) ifadesinde ise metonimik metafor yapısı vardır. Kişinin cömertliği yine onun bir uzvu olan el üzerinden verilmiştir. kulakı sak (2481) farkındalık anlamındadır. Düşünce ve işitme organı olan kulak düşünce soyut kavramı ile farkındalık olarak metaforlaştırılmıştır. Aḍak beküt- (1855) ifadesinde sağlam basmak, hayatta kalmak ifadesi ayak uzvunda kavramlaştırılmıştır. et öz bulnı (3642) vücudun esiri anlamında olan ifadede esirlik ifadesi için vücut kapsayıcı durumundadır. Nefs butını (3635) nefsin beli ifadesinde ise nefs soyut kavramı insan bedeninin parçası olan bel ile kişileştirilmiştir. Hava boynı (heva boynu) (1375) ifadesinde boş arzu ve istek soyu kavramı insan ontolojisinin parçası boyun ile somutlaştırılmıștır. Boynunu kopar-, boynunu al-, boyu ver- gibi yok etmenin kavramlaştırıldığı ifadelerinde olduğu gibi heva, arzu, istek gibi olumsuz özelliklerin yok edilmesi gerektiği için boyun ile kavramlaştırılmış olabilir. Sukluk közi (3626) ifadesinde ise bütünparça ilişkisine dayalı metonimik bir metafor yapısı vardır. Tamahkarlık insana has bir özelliktir ve bu özellik insanın göz organı ile metaforlaștırılmıștır. Buradan hareketle cömertlik, ihtiyatlılık, farkındalık, sağlam durmak, nefsine hakim olmak ve aynı zamanda esirlik kavramları insan ontolojisinde kavramlaştırılmıştır.

Doğruluk, erdem, iyilik, kötülük, öfke gibi soyut zihinsel kavramların nasıl yansıtıldı̆̆ı ve nelerle kavramsallaştırıldığının metafor açıklamalarında önemli bir yer tutmaktadır. Örneğin eserin önemli kavramlarından doğu ve doğruluk soyut kavramlarının metaforik kavramlaştırmaları görülmektedir. köni yol (393), könilik yolug (1126), egri yol (2023) ifadelerinde doğru, doğruluk, yanlış soyut kavramlarının yol ile kavramlaştırıldığı görülür. Yol somut alanı doğru, doğruluk ve eğri soyut kavramlarını somutlaştırarak varlık- madde metaforu ortaya çıkarmıştır. Yol sözcüğü de tarihi Türk dili alanının özellikli bir sözcüğ̈̈dür. könilikte bul- (1292) ifadesinde ise bul- eylemi doğruluk soyut kavramını kapsayıcı metafor olarak kavramsallaştırmıştır. Doğruluk kadar kullanılan iyilik sözcüğünün de metaforlu kullanımları görülür. Edgüsi teg- (458) ifadesinde çok anlamlı kullanımı ile metaforlu yapılar oluşturan teg-/ulaşeylemi iyilik soyut kavramını somutlaştırarak taşınan nesne- madde olarak metaforlaştırmıştır. Eḍgü yaşı (1640) canlılara özgü yaş kavramı da iyilik soyut kavramını kişileştirerek metaforlaştırmıştır. Merhamet sözcüğü de Kutadgu Bilig'de bilişsel (ontolojik ve epistemolojik) olarak metaforlu kullanılan soyut sözcüklerdendir. Baġır ve merhamet arasında bilişsel olarak bağlantı da vardır. $\mathrm{Bu}$ ifadenin sistemli olarak tarih boyunca kullanılması da onu kültürel metafor 
yapmıştır. Bağırsız (6576) sözcüğü vefasız kimseler şeklinde anlamlandırılmıştır. Bağırsak ve bağır Tarihi Türk dili dönemlerinde merhamet olarak yerini almıştır. Bağır, kalp/yüreğin bulunduğu yerdir. Aileler çocuklarını bağırlarına basarlar. Çok acı çekenlerin bağırları yanar. Günümüzde bu şekilde kullanılan sözcük Kutadgu Bilig'de merhametsiz, vefasız olarak baġırsız şeklinde kullanılmıştır. Ayrıca burada metonimik bir kullanım da vardır. Baġırsız kişi yerine parça bütün ilişskili olarak kişinin sadece vasfi iletilmiştir. Gönülden bağlan- olarak metinde verilen bağır isin- (isin bağır) (1507) ifadesinde bağır önemli bir kültür sözcüğüne gönüle metaforik olarak kullanılmıştır. Baġır sözcüğünün kullanımında olduğu gibi mertlik, yiğitlik kavramı kögüzlüg (2282) şeklinde yine aynı beyitte geniş yüreklilik anlamında kọ̈üllüg (2282) ifadeleri metafor olarak kullanılmıştır. Bağır gibi bilişsel olarak da zorluklara göğüs germek ifadesinde olduğu gibi zorluklarla baş edenler mert kimselerdir. Bu nedenle mertlik ve kögüz arasında bilişsel bir bağ kurulur. Aynı bağlantı merhamet soyut kavramının metinde kavramlaştırıldığı gönül soyut kavramı da bilişsel bir bağlantı içindedir.

Kutadgu Bilig'de ögi bilgi kin (2481) ifadesinde ise kin- genişlik yön kavramı ög/akıl ve bilgi soyut kavramlarını metaforik olarak yapılandırmıştır. Burada dolaylı olarak bir yönelme metaforu görülmektedir. Biligke tepiz (2949) ifadesinde ise deniz bilgi için kapsayıcı olmuştur ve bilgi soyut kavramı da taşınan nesne/ madde görevini görmüştür. Yine bilgi kin (6488) ifadesinde de yön ifade eden kin - genişlik kavramı bilgi soyut kavramını yönelmeli metafor olarak kavramlaştırmıştır. Yine eserde sistemli olarak kullanılan akı1/ uḳuş sözcüğünün metaforlu kullanım alanlarının yaygın olduğu görülmektedir. Ukuş yolı (6104) ifadesinde akıl soyut kavramı yol yer alanı ile kavramlaştırılarak varlık- madde metaforu oluşturulmuştur. Ukuşska ögüz (2949) ifadesinde ögüz- nehir sözcüğü ukuş soyut kavramı için kapsayıcı olmuştur. Ukuşakıl soyut kavramı böylece taşınan nesne/madde şeklinde metaforlaşmıştır. Kutadgu Bilig'in en önemli sözcüklerinden biri de sakınç sözcüğüdür. Sakınç- düşünce sözcüğü Kutadgu Bilig'de farklı anlamlarda da kullanılmıştır. Düşünce, keder, ihtiyat,/ farkındalık, hesap anlamlarında da kullanılan sözcük farklı metaforlar şeklinde de görülmektedir. sakıış bir- $(1363,6378)$ hesap vermek ifadesinde bir- eylemi sakınç soyut sözcügünü somut madde şeklinde varlık- ontolojik metafor bağlamında metaforlaştırmıştır. sakııçın sız- (6587) ifadesinde sakınç keder veya üzüntü anlamlarına gelebilir. Sakınçla, düşünceyle erimek ifadesinde sakınç keder ateş maddesi olarak metaforlaştırılmıştır. Saklık közin (2833) ifadesinde farkındalık, ihtiyatlı olmak soyut kişi özelliği yine insan ontolojisine ait köz uzvu ile ontolojik bağlamda metaforlaştırılmıştır. Düşünceli, ihtiyatlı olma hali zihinsel bir durumdur. Bu zihinsel durum yine beyne en yakın merkez gözle kavramlaştırılmıştır.

Kutadgu Bilig'de üzerinde durulan en önemli konulardan biri de söz kavramıdır. Söz soyut kavramını farklı bağlam ve metaforik ifadelerde görebilmekteyiz. Sözüg k1y- (338), söz 1ḍ(574), söz süçig (1696), açıg söz (2577), sözü uzat- (2853) ifadesinde uzat- eylemi söz soyut kavramını somutlaştırmıştır. sözüg bışur- (4036), sözüy tẹle- (4875), sözin kes- (6420), sözü tüket- (6626) metaforik ifadelerinde kıy-, 1d-/göndermek, pişir-, tart-, kes-, tüket- eylemleri ile ac1 ve tatlı sıfatları beraberinde kullanıldıkları söz soyut kavramını somutlaştırarak varlıkmadde metaforu oluşturmuştur. Sözke ulı ur- (921) ifadesinde söz soyut kavramına ul/temel oluşturmak söz soyut kavramını taşınan nesne/madde olarak metaforlaştırmıştır. Sözin yortt(1124) ifadesinde ise metinde farklı anlamlarda görülen yorıt- eylemi söz soyut kavramını tașınan nesne/madde şeklinde kavramlaştırmıștır. Aynı zamanda söz bu șekilde emir, hüküm olarak kullanılmıştır. Sözü kizle- (2683) metaforik ifadesinde ise bir şeyi/ bir kişiyi saklamak gizlemek olarak kullanılan eylem söz soyut kavramını somutlaştırarak taşınan nesne/madde olarak kavramlaştırmıştır. Tilin söz basıp (6308) ifadesi Kutadgu Bilig'de ağzını kilitleşeklinde geçer ve bastırmak, kapatmak anlamlarına gelen bas- eylemi söz soyut kavramını somutlaştırarak taşınan nesne/madde şeklinde metaforlaştırmıştır. Söz aç- (6452) ifadesinde parça bütün ilişkisine bağlı metonimik bir metafor görülmektedir. Burada somutlaştırmaya 
dayalı varlık- madde metaforu görülmektedir. Söz suw1 (6628) ifadesinde tazelik olarak anlamlandırılan suw sözcüğü söze kaynağını bitkilerden alan somut madde (meyve, çiçek vs) olarak metaforlaştırır. Sözü sözke diz- (6616) ifadesinde söz+ke kapsayıcı bir yer durumundadır. Dizilen söz içi kapsayıcı durumundadır. Diz- eylemi ise söz soyut kavramını (ince bir madde, boncuk vs) somutlaştırmıştır. A $\dot{g}_{1 Z d}$ ın ara ot ara suw (2686) ifadesinde ise ateş ve su söz için metaforik olarak kullanılmıştır. Söz olan ateş ve su ağızdan çıktığı için taşınan nesne/madde durumundadır. Ağız ise bu sözler için kapsayıcı durumundadır. Ağzından kaç-, ağızdan söz bir defa çıkar, ağızdan çıkan söz şeklinde günümüzden kullanımları da vardır.

Kutadgu Bilig'de değerler ve adalet bağlamında "kapı" somut sözcüğü kaynak alan olarak metaforlaştırma yapıldığı görülmektedir. Kövecses'e göre bir metaforda kaynak alan hedef alana göre daha somut olmalıdır. Kutadgu Bilig'de veya başka bir metinde metaforların kültürel özelliklerinin belirlenebilmesi için kaynak alanların önemli bir yeri olduğunu söyleyebiliriz. erej kapg $\dot{g}_{1}$ (2992) huzur kapısı ifadesinde huzur soyut sözcüğü kapı somut sözcügüü ile somutlaştırılarak varlık madde metaforu şeklinde kullanılmıştır. Arzu tilek kapug (6412) ifadesinde de kap1 somut sözcügü arzu ve dilek soyut kavramlarını somutlaştırarak metaforlaştırmıştır.

Kutadgu Bilig'de zaman soyut kavramının da geniş metaforik kullanım alanlarının olduğu görülmektedir. Öd kün yawa kı1l- (6431) zamanı boşa harcamak ifadesinde harca- eylemi zaman soyut kavramını somutlaştırmışıır. Ayrıca burada boşluk bir kapsayıcıdır. Zaman da aynı zamanda taşınan nesne/maddedir. Ödü kel- (554) metaforik ifadesi de bir varlık madde metaforudur. Zamanı gel- ifadesi Türk ve İslam kültürü için önemli bir ifadedir. Kutadgu Bilig'de ayrıca her işin zamanında olabileceği farklı bir beyitte ifade edilmiştir. Ödü yetil(1099) vakti gel- ifadesi de ölüm zamanını karşılamak için kullanılmıştır. Burada hem bilişsel hem de bir kültürel metafor kullanımı vardır. Bilişsel olarak yetil- eylemi zamana bir somutluk kazandırırken, ödü yetil- ifadesinin ölüm zamanını karşılamasıyla da kültürel bir metafor kullanımı görülmektedir. Ödke tutug (1211) zamana rehin ol- ifadesinde zaman herkes için bir kapsayıcı durumdadır. Kutadgu Bilig'de ve Türk kültüründe de böylece zamanın kapsayıcı özelliğinin olduğunu vurgulayabiliriz. Ödine küd-(3530) vaktini bekle- olarak anlamlandırılan ifadede bekle- eylemi zamanı iki şekilde bir kişiyi ve bir şeyi beklemek olarak kavramlaştırmıştır.

Kutadgu Bilig'de yaşam, hayat anlamını karşılayan "tiriglik" sözcüğünün de metaforikal olarak kullanımları görülmektedir. Tiriglik tüket-(6521) ifadesinde hayatın sonlu/sınırlı bir kaynak olduğu anlaşılır. Değerli olan her şey zaman, para, doğal kaynaklar vs. tükenir varlıklardır. Tüket- yok et- eylemi hayat sözcüğünü zaman, para, doğal kaynaklar gibi somutlaştırarak varlık- madde metaforu oluşturmuştur. Tiriglik $1 d$ - (6545) hayat harca- olarak verilen ifadede hayat para, zaman gibi somutlaştırılmıştır. Tiriglikni yawalıkka 1d- (6527) metaforik ifadesinde yawalık hayat için kapsayıcı olmuştur. Tiriglik- hayat ise taşınan nesne/madde durumunda olmuştur. Burada hayat sözcüğü için evrenseldir diyebiliriz. Çünkü Lakoff- Johanson'un Metaphors We Live By eserinde para, zaman, hayat gibi değerli varlıkların harcanabilir olduğunu bu nedenle birbirleriyle aynı özelliklere sahip olduğu vurgulanmıştır.

Tarihi Türk dili alanı ve Türkiye Türkçesi için bilişsel alanın konusu olan soyut duygu durumları Kutadgu Bilig'de daha çok somutlaştırma ve kapsayıcı metafor oldukları görülmektedir. Örneğin ulaş-, uğramak, başa gel-, dokun-, elde et- gibi farklı anlamlarda kullanılan teg- eylemi emgek tegir- (432), yası teg- (781) gibi metaforik ifadelerde emgek/zahmet ve yas/zarar soyut kavramlarını somutlaştırarak varlık- madde metaforu; beḍüklükke teg-(2233), yük teg- (1876), bağırsaklık tegür- (5904), edgüke teg-(1124), agirlıkka teg-(1125), muĐka teg-(6574), tilekke teg-(155), ülüg teg-(832), ülüg tegür-(3726), inçke teg-(1044), erejke teg-(5568) ifadelerineki soyut kavramları ise ula-, elde et-, kazan- anlamlarında kullanılan teg- eylemi taşınan nesne/madde metaforu olarak kavramlaştırmıştır. Ayrıca bu soyut kavramlar ifade ettikleri 
anlamlar için (başarıl1, merhametli, sıkıntılı, huzurlu olma) yer alanları metaforu olmuşlardır. Tilek sür- (6535) metaforlu ifadesinde sür- eylemi süreklilik ifade eden bir fiildir. Can sürşeklinde olduğu gibi devamlılık gösterir. Dileğinin yerine gelmesinde süreklilik kavramı ise onu elde etmek isteğinde kararlık şeklinde algılanabilir.

Kök, dip, son sözcükleri de Kutadgu Bilig'de metaforik ifadelerde kaynak alana hizmet eden önemli bir sözcüktür. Can köki (2909) bir şeyin can kökü gibi sevilmesi aşırılığı ifade etmektedir. Burada kök sözcüğü can soyut kavramını kaynağını bitkiden alan varlık madde metaforu şeklinde kavramlaştırmıştır. Dünyag tüpi (3089) dünyanın dibi ifadesinde bir yönelme vardır. Dip olumsuzluğu ifade eder. Beyitte dünyanın dibinin de bataklık olduğu ifade edilmektedir. Türk kültüründe aşağı yönelimler bazı istisnalar dışında olumsuzluk ifade eder. Yukarıya yönelimler ise olumlu olayları ifade eder. Kök (2015) sözcüğü beyitte kanun ve ihtiyatlılık kavramlarının esas, olmazsa olmaz anlamlarını karşılamaktadır. Bu beyitte kanun ve ihtiyatlılık soyut kavramlarına kök sözcügü kaynağını bitkiden alan varlık- madde metaforu olarak kavramlaştırmıştır. Kişi Sopı (6595) kişi artığı ifadesinde de soy sözcügü insanı tükenebilir bir madde olarak metaforlaştırmıştır.

Kutadgu Bilig'de yaşam, ölüm, kıyamet gibi kavram alanlarına ait metaforlar oldukça fazladır. Örneğim insan yaşamını karşılayan pek çok metaforik ifade vardır. Tiriglik küni (ömür) (1122), kün (1663) (ömür), inçin salın (2692) (huzurla yaşa-), tur- (3582) (doğ-), törü(4504) (doğ-), can sür- (6623) (hayat), küni yarut- (6460) (güneşi parlamak) ifadeleri metinde hayat, ömür soyut kavramlarını karşılamıştır. Tur- (3582), törü- (4504) şeklinde verilen doğeylemi metinde hem oğul hem de kız çocuğu için kullanılmıştır. Can sür- (6623) ifadesinin de hayat, yaşamı devam ettirmek anlamlarını karşıladığını söyleyebiliriz. Sür- eylemine hayat sür-, araba sür- eylemlerinde de rastlarız. Sürülen hayat da bir yolculuktur. Bu hayatta pek çok şeyle karşılaşırız. Yola/yolculuğa bir taşıtla çıkarız. Taşıtı sürerken karşılaşacağımız her durumla hayatı sürerken de karşılaşabiliriz. Bu da epistemolojik olarak kaynak ve hedef alandaki ortaklıkları göstermektedir. Güneş, sıcaklık, yaşam demektir. Beyitte geçen kıyametin güneşinin parlaması artık onun hükmünün geçeceğine işaret eder. Bir şeyin güneșinin parlaması onun varlığının devam edeceği anlamına gelir. Küni yarut- (6460) ifadesi de bu nedenle hayat anlamını karşılamaktadır.

Ay Toldı ve Odgurmış'ın ölümlerinin yaşandığı Kutadgu Bilig'de ölüm kavramını karşılayan metaforik ifadeler de çokça bulunmaktadır. Toprak, yer, karın ve yılanın kapsayıcı metafor olarak kavramlaştırıldığı yiri töşen- (237), kara yer katında tüz yat- (1427), kara yirke kir(1512), karınka kir- (1515), yılanka bir- (1515), yağız yirke ildür- (3081), yeri eşün- (3785), yer bol- (4590), kara yir bol- (6400), kara yir töșen- (6444), yirke (yalı̄) kir- (6553) ifadeler bulunmaktadır. Ölümün yönelmeli metafor olarak kavramsallaştırıldığı yaşıl kökke yol al(1518) ifadesinde göğe doğru yol al- yukarı doğru bir yönelim ifade eder. Yukarı doğru olumlu bir yönelim ölüm olumsuz kavramı için kavramsallaştırılmıştır. Canı çık- (1395), yitip bar(1522), sız- (yirde) (4723), kirip yat- (4820), kara yir tuşı (6441) ölüm için kullanılan yönelmeli metaforlardır. Yine ölüm kavramının somutlaştırma yoluyla oluşturulan varlık madde metaforları da vardır. ahır tın (394) ifadesinde son kavramı ile nefesin tükenebilir sınırlı bir kavram şeklinde somutlaştırılmıştır. Candın el yu- (1115) yönelmeli metaforik ifade de ölüm için kullanılmıştır. Tiriglik tüken- (1099) hayatı tüken-, öḍü yetil- (1099) zamanı gel-, tını kesil- (1520) kesil- eylemi tın/ nefes kavramını somutlaştırarak varlık- madde metaforu haline getirmiștir. Ölüm kavramını metaforik olarak karşılayan fiiller ise köç- (köç-gü) (1445), kan dök- (6440) bar- (76), işi itil- (6444) şeklindedir. Tirigliki tol- (1169) ölüm için kullanılan hayatı dolifadesinde dol- eylemi tiriglik/hayat kavramını kapsayıcı metafor olarak kavramlaştırmıştır. Ölmek eylem ilgili olan anıt, mezar kavramlarının karşılı̆̆1 olarak kara yir koyı, yağız yir oyı (3570), kara yir katı (4820) metaforik ifadeleri geçmektedir. Aynı şekilde mezarlık için ise 
eserde ölügler toyı (4512) geçmektedir. Toy sözcüğü Tarihî Türk dili alanında devlet, yönetim kavram alanında kullanılan bir sözcüktür. Kutadgu Bilig'de çok farklı bir anlamda kullanılmıştır. Yaşayanların nasıl bir düzeni varsa, mezarların da bulunduğu yerin bir düzeni olduğunu tarihi anlamını bildiği toy sözcüğü ile karşılamış olabileceği de düşünülebilir. Toy sözcüğü Kutadgu Bilig'de karargah olarak da kullanımı da göz önünde bulundurulmalıdır. Kutadgu Bilig'de ölüm anının gelişi ise ecel tut- (1143) ve ölüm tut-(1125) ifadeleri ile karşılanmıştır.

Kutadgu Bilig'de ölüm/din kavram alanına giren kıyamet kavramını da metaforik ifadelerin karşıladığı görülür. Könilik küni (30), Ulug kün (32), kopg்u (47) metaforik ifadeleri kıyamet için kullanılmıştır. Bu bağlamda dünya için misafirhane (3561), börk ew içi (3723), içi yılan dolu tünek (5421) adlandırmaları kullanılmıştır.

Ölüm/ Din kavram alanı için kullanılan diğer metaforik ifadeler ise kefen için iki böz (6552), sal için eḍersiz yığaç (1428), dünyada işlenen sevaplar veya alınan dualar veya insanın dünyadayken ahirette kendisini karşılaması için yapılan dualar köç (göç yükü) (1445), hayattayken insanın yaptığı iyilikler ve kötülükler tarlag (6555) metaforlarıyla karşılanmıştır.

Dinî kavram alanında görebileceğimiz bazı soyut kavramlar kapsayıcı metaforlar olarak kavramsallaştırılmıştır. Hem Kutadgu Bilig metni için hem de günümüz Türkçesi için bilişsel ve psikolojik olarak olumsuz kavramların- eylemlerin kapsayıcılık özelliklerinin olduğunu ifade edebiliriz. Dünyaka könül bir- (1171) ifadesinde insanın gönlünü veya fikrini dünyaya vermesi bir yönelme ifade etmesinin yanında dünya mekanına kapsayıcılık özelliği de atfetmiştir. Ölümke toǵ- (1201) ifadesinde ise ölüm için doğmak anlamı vardır. İnsanların hayattan ölüme doğru geçişleri hayatı kaynak ve kapsayıcı ölümü de yönelim yapılan yer yani kapsayıcı olarak göstermektedir. Fesadka katıl- (1334) ve haramka katıl- (1433) ifadesinde ise katıl- eylemi fesad ve haram soyut kavramına kapsayıcı metafor özelliği kazandırmıştır. bayatka sığın- (2158) metaforik ifadesinde ise bir yere bir şeye sığın- eylemi bayat kavramına (Allah'a) kapsayıcı metafor özelliği kazandırmıştır. Bilişsel olarak da Allah her şeye ve herkese hakimdir. Havaka bulun bol- (3994) nefis ve hevaya bağlı olmak, onlara esir olmak heva soyut kavramına tabii olunan yani hevaya kapsayıcı metafor özelliği kazandırmıştır.

Tapuǵka uḍ- (6385) ibadete uy- metaforik ifadesi tapug்/ ibadet kapsayıcı metafordur. Uy-, tabii ol- eylemi ibadet soyut kavramına kapsayıcı metafor özelliği kazandırmıştır. Aynı şekilde yazukka basıt- (6558) ifadesinde basit- / gir- eylemi günah soyut kavramını kapsayıcı metafor olarak kavramlaştırmıştır. Dua $1 d ̣-(6504)$ dua gönder- eyleminde ise $1 d$-/gönder- eylemi dua soyut sözcüğünü somutlaştırarak varlık- madde metaforu meydana getirmiştir. Yazuk tökül(5982) günahı dökül- ifadesinde ise dökül- eylemi günah soyut sözcügüne su metafor anlamını katmıştır. Kaynak alanı su, hedef alanı günah olan bu metaforik ifade kaynağını sıvı maddelerden alan varlık- madde metaforudur. Yazuk yarlıka- (6509), yazuk keçür- (6511) günahları bağışlamak ifadesinde ise bir şeyi bağışla- ifadesi günah soyut kavramını taşınan nesne/madde şeklinde metaforlaştırmıştır. Ni'met iḍisi (6449) ifadesinde ise sahip, sahibi, sahip ol- ifadeleri nimet kavramını taşınan nesne/madde metaforu olarak kavramlaştırmıştır. İdike tapın- (6558), bayatka tapug ḳl- (6560) ifadelerinde ise Allah'a tapın- ve ibadet etmek eylemleri yukarı doğru bir yönelim ifade eder. Aynı zamanda bilişsel ve dinî inançlarımız doğrultusunda yaptığımız ibadetler ve ettiğimiz dualar Allah'a ulaşır. Bu nedenle Allah aynı zamanda kapsayıcıdır. Teprilik (6479) kavramı ise Kutadgu Bilig'de Allah rızası deyimini karşılamaktadır.

Aynı zamanda Azrail için okıgçı (davetçi) (1473), ölüm tutgakı (1351); Ahiret için yarınlık iş (1208, 1278), uzun yol (1473); Dünyadaki yapacağımız işler için itingü (1473), itin- (3558), ewin it- (3560); dünyadaki hayat için yol (3560); ölümlü kişi için yorığlı kişi, köçügli kişi (3560) metaforik ifadeleri kullanılmıştır. Kutadgu Bilig'de geçen din yolı (6498) ifadesinde din soyut kavramı yol somut alanı ile metaforlaştırılmıştır. Böylece yol sözcüğ̈̈ ile oluşturulmuş varlık- madde metaforu oluşturulmuştur. Ölüm kapgiı (3531) ifadesinde de ölüm kavramı kapı 
ile varlık madde metaforu ile kavramlaştırılmıştır. Kapı iki mekanı birbirinden ayıran bir araçtır. Kapandığında diğer mekana veda ederiz ve yeni mekana geçiş yaparız. Hayattan ölüme geçiş de bu şekilde bilişsel olarak kapı metaforu ile kavramlaştırılmıştır. Yay kur- (6397) ifadesi ise bağlamında Tanrı'ya karşı gelmek şeklinde kullanılmıştır. Beyitin daha derinde tarihi bir olay barındırabilir. Bu nedenle kültürel olmasının yanında tarihsel bir metafor durumundadır.

Kutadgu Bilig'de kullanılan yarmak kulı (6476) paranın kulu ifadesinde para maddesi kapsayıcı olarak, bugün dilimizde yaşayan çalışmak anlamına gelen ve iş sözcüğünün kapsayıcı olarak kavramlaştırıldığ 1 işin işle- (6346), gurbet durumu gariblık yeri (477) ifadesinde gariblık soyut kavramı taşınan nesne/madde olarak yer kavramı ise gariplik için kapsayıcı olarak metaforlaştırılmıştır. Sinirlenmek ve öfkelenmek eylemleri için kullanılan Otı tol- (637) ifadesinde ise tol- eylemi ateş somut kavramını kapsayıcı olarak kavramlaştırmıştır. Yirke çal- (1056) ifadesinde yönelmeli bir metafor görülmektedir. Çal- eylemi bugün bazı bölgelerde hala yaşamaktadır. Aşağı doğru bir yönelim gösteren bu metafor olumsuz bir bakış açısına sahiptir. Esen edgü kal- (1162) deyimi bugün esen kal- ifadesinde yaşamaktadır. Uygur döneminden kalan bu ifadede esen ve edgü soyut kavramları insan için kapsayıcı metafor özelliği göstermektedir. Kişiler tili bolmasa bir (1593) beyitte geçen bu ifade ağız birliği etmek anlamındadır. Torka kir(3565) metaforik ifadesinde tuzak kapsayıcı olarak kavramlaştırılmıştır. örtüg kötür- (5818) anlam ile ilgili olan bu metaforik ifadede yönelme metaforu görülmektedir. kurç yüreklig (5911) tunç yürekli ifadesi metaforik olarak cesaret ve korkusuzluğu ifade eder. Yoluy onça (1392) sağ sözcügü Tarihî Türk dili alanı ve İslâmiyet içerisinde de olumlu bir anlama sahiptir. Kövecses sağ ve sol kavramları ile oluşturan metaforlar için zihinsel metafor ifadesini kullanmıştır (Kövecses 2009, 118-119). Burada yol için on/sağ yönü kapsayıcı olarak kavramlaştırılmıştır. Torku kalkan (3288) ifadesi metaforda uyumsuzluk konusunu açıklayabilir. İpek/torku ve kalkan birbirlerinden ayrı özelliklere sahiptir. Yani kaynak ve hedef alan arasında ortaklık yoktur. Bu nedenle metafor ifadesinin kullanıldığı bağlama bakılması gerekir. Dünyanın üzerindeki karanlık sis perdesini, gecenin sabaha ulaştığını ifade etmek için ipek kalkan yapısı kullanılmıştır.

Kutadgu Bilig'de sosyal hayat bağlamında kullanılan kültürel metaforlar da vardır. Tuz ekmek iḍisi (1191), tuzı etmeki kin (2274), tuz ekmek yitür- (4222) ve tuz ekmek hakı (5797) Tuz ve ekmek kavramları Türk kültürü için önemli ve özellikli kültür kavramlarıdır. İnsanlarla paylaşmak, bir kişi açken tok uyuyamamak Türk insanının özelliklerindendir. Yabancı bile olsa bir misafir yedirilir içirilir. İkinci olarak ise insanlar bu paylaşımlarından dolayı kendilerini sorumlu hissederler ve birbirlerine vefa göstermeye gayret ederler. Bu ifadenin yanında destanlar döneminden itibaren gelen ata hurmeti (6491), awıçga sözi(1638) atalar sözü ifadeleri de yer almaktadır. Bu ifadeler Türk dilinin diğer dönemlerini de hatırlatıp gönderme yaptığı için kültürel olmalarının yanında aynı zamanda tarihsel metaforlardır.

Bir yönetim kitabı, siyasetnâme olması itibarıyla Kutadgu Bilig'de yönetim kavram alanında pek çok metafor yapısı vardır. Başı bar- (167) ifadesinde baş insan bedeninin üst kısmındadır. Bir önem ifade eder. Başı bar- ifadesi başının gitmesi, öldürülmesi anlamına gelir. Ölüm ifadesi yerine insan için hem bilişsel hem de ontolojik olarak önemli olan başın elden gitmesi şeklinde metaforik olarak aktarılmıştır. Çawı küsi yaḍıl- (458) burada kaynağını sıvı maddeden alan metafor yapısı vardır. Kaynak alan su ve hedef alan çaw, küsi olan bu ifadede yayıl- eylemi çaw, ün, şöhret gibi soyut sözcükleri su olarak kavramlaştırmıştır. Tapug̣ka kir- (481) ifadesinde tapug்/hizmet kapsayıcı olarak kavramlaştırılmıştır. Hizmet kişi için kapayıcı durumunda olmuştur.

Kutadgu Bilig'de yer alan dört şahsiyetin adlarını (Kün Togdı, Ay Toldı, Ögdülmiş ve Odgurmış) metaforik ifade olarak kabul edebiliriz. Bu adların yanı sıra metinde geçen seslenme ifadelerinin de metaforik bir ifade olduğu görülmektedir. Kutadgu Bilig'de yer alan dört sembolik şahsiyet Kün Togd1, Ay Toldı, Ögdülmiş ve Odgurmış adlandırmalarında düşünce ve dünya görüşünün yansıtıldığ 1 metafor özellikleri görülmektedir. Kün Togdı'nın Bilge Kağan ve Kül 
Tigin devamında bir sürekliliğin temsilcisi olarak Tanrı'nın yeryüzündeki temsilcisi olması ve Ay Toldı'nın güneşten yani hükümdardan sonra gelen önemli şahsiyet (ay’ın gökyüzündeki ikincil fonksiyonuna da uyarak) olması nedeniyle kültürel metafor durumundadır. Ayrıca her iki şahsiyetin adlandırılması mitolojik ögelere bağlıdır. Türk devlet geleneğini, Türk düşünce sistemini simgelemektedirler. Ögdülmiş ve Odgurmış da Türk düşüncesini simgeleyen metnin önemli şahsiyetleridir. Odgurmış'ın zaman içinde yapılan çalışmalarda Budist, Hint, İslam kültüründeki kimliklerle bağdaştırılması da onun mitolojik tarafının bulunduğunu göstermektedir. Ay Toldı (69) Devleti, devletin vezirini simgeleyen Ay Toldı ise ayın doğması şeklinde döngüsel bir eylemi ifade eder. Kavramsal olarak ay bir kapsayıcı ve taşıyıcı nesne durumundadır. Döngü metaforu olarak adlandırabileceğimiz "Ay Toldı" kapsayıcı metafor ve taşıyıcı nesne metaforuna örnektir.

Özellikle Kün Togdı ve Ay Told 1 şahıs isimleri doğal bir döngüyü ifade etmektedir. Kapsayıcı ve Taşıyıcı Nesne metaforları olmalarının yanında birer döngü metaforuna örnek olan bu şahıs adlarının kültürel bağlamda her ikisinin de kökenleri Türk mitolojisine bağlıdır. Bu bağlamda mitoloji ve metafor arasında kurulan bilişsel bir bağ sonucu kültürel metaforlar ortaya çıkmaktadır.

Metinde karşıllklı konuşmalarda yapılan hitaplarda da bu şahsiyetlerin özellikleri kendileri yerine kullanılmıştır. Burada yer alan metaforik ifadeler kaynak alan ve hedef alanlarına göre haritalandıklarında kavramsal metafor bağlamında varlık madde metaforu (könli süzük, kılkı tüzün), kapsayıc1/taşıyıcı metafor (ajun tutguçı, bilgi tolu), yönelmeli metafor (bilgi batıg) oldukları görülmektedir. Somut kavram özelliklerinin soyut kavram özelliklerini yapılandırması yanında soyut kavramlarında yine bir soyut kavramı yapılandırdığı görülmektedir ( ersig akı).

Odgurmış'ın Hükümdarla konuştuğu bölümde yer alan ay siğun (5111) ifadesinde Odgurmış hükümdara "ay sıgun" olarak hitap eder. Sıgun (dağ keçisi) Türk kültürüne ait bir sözcüktür. Odgurmış'ın bu ifadeyi kullanması onun Türk kültürüne de hakim olduğunu göstermesinin yanında dağ keçisinin barındırdığı özelliklerin hükümdarda olması gerektiğine işaret eder. Aynı zamanda tarihi Türk dili alanının önemli bir simgesidir. Orijinal metinde hükümdara sadece ay sıgun olarak seslenir. Bu nedenle kavramsal bağlamda kaynağını hayvan özelliklerinden alan bir varlık madde, ontolojik bir metafor vardır.

(törü birle) atın kopur- (103) ifadesinde bir kişinin şöhretinin yayılması, bir devletin yönetimini üstlenebilmek adın yükselmesi ile ifade edilmiştir. Kop- eylemi olarak kullanılan yükselmek yukarı doğru bir yönelim ifade eder. Bu eylem ad soyut kavramına somut bir madde özelliği kazandırmıştır. Aynı zamanda kanun ile yükselmesi ifadesinden hareketle de Kopeylemi kanun soyut kavramını somut bir madde şeklinde (basamak/merdiven) yapılandırmıştır. sakııçcın tügük/ kögli tüşük (1111) üzüntüyü ifade etmek için sakınç/ düşünce soyut kavramı tüg-/ düş- eylemi ile kavramlaştırılmıştır. Düşüncenin aşağıda olması üzüntü ve olumsuzluğu ifade eder. Dolayısıyla burada soyut sakınç/ düşünce anlamı yönelmeli metafor şeklinde ifade edilmiştir. batıg hendese sakış̧ı (2786) ifadesinde aşağı doğru yönelim gösteren bir derinlik yön metaforu vardır. Türk dilinde yer yer aşağı yönelim olumsuzluk ifade edebilir. Fakat burada olumlu bir metaforik yapı vardır. Hendese/ hesap işine önem verilmesi gerektiğini ifade eden ve dikkat edilmesi gerektiğini vurgulayan bir yapı vardır. Düşünceyi gerektirir. Burada kaynak alan deniz, okyanus gibi yerler olabilir. Çünkü derinlik genelde sular coğrafyasında kullanılmaktadır. Burada deniz, okyanus kavramı düşünce, önem verme hedefi üzerine yapılanmıştır. Kaynak Alanı deniz, okyanus derinliği ve hedef alanı ise düşünmektir. kaş tüg-(4756) yönelim metaforu yanında aynı durumu "tügük yüz" "çatık yüz" ifadesinde de görürüz. Sinirli, hiddetli olma hali için insan bedenine ait bir parça yüz kaynak alan ve aynı zamanda bir kapsayıcı durumundadır. Kaş çat- ifadesinde olduğu gibi çatık yüz ifadesinde de hareket aşağı doğru bir yönelim gösterir. Yüzün de asık olması sinirlilik ve hiddetli olma halini niteler ve olumsuzluk ifade eder. Aynı 
durum yine kaş tüg- kaşlarını çatmak ifadesinde de bulunmaktadır.

\section{Sonuç}

Çalışmada Kutadgu Bilig'de yer alan somutlaştırma, kapsam, yönelim metaforları yoluyla oluşturulmuş kavramsal metaforlar bilişsel ve kültürel kökleri açıklanarak verilmiştir. Kutadgu Bilig'de soyut duygu ve değer kavramları, ölüm ve hayat kavram alanları, hitaplar ve şahıs adları bu çalışmada kültürel metafor bağlamında sınırlı miktarda aktarılmıştır. Bütün kültürlerde olduğu gibi mutluluk, üzüntü, öfke, memnuniyet soyut kavramların insan ontolojisinde göz, el, bağır, boyun uzuvlarında toplandığı görülmüştür. Soyut kavramların özellikle gönül, huzur, dilek gibi soyut kavramların kapsayıcı yer alan metaforu görevinde olduğu görülmüştür. Ayrıca bilgi, iyilik, akıl, söz, yaşam/hayat, doğruluk gibi soyut kavramlar da taşınan nesne/madde metaforları olarak görülmektedir. Doğmak ve yaşamak anlamlarına gelen tur- eyleminin metinde hem erkek hem de kız çocukları için kullanıldığı dikkati çekmiştir. Ölüm kavram alanına giren kavramlar bilişsel ve psikolojik bağlamda kapsayıcı metafor olarak metinde görülmektedir. Devlet kavram alanında yer alan metaforların sadece birkaçına değinilmiştir. Bu metaforların da kaynağını maddeden alan varlık-madde metaforu, kapsayıcı metaforlar olduğu görülmektedir. Şahıs adlarında ise Kün Togdı ve Ay Toldı üzerinden kültürel-kavramsal metaforların açıklaması yapılarak düşünce ve dünya görüşünü yansıtan mitolojik bağlamlı kültürel metaforlar olduğu görüşü vurgulanmıştır. Hitap konusunda ise Kutadgu Bilig'de yalvarma, uyarı, övme bağlamlarında Türk kültürünün güç, bilgelik bildiren adlandırmalar kullanılmıştır. $\mathrm{Bu}$ hitaplar tarihsel kökleri olan kültürel metaforlardır. Yönelmeli metaforlarda ise düşünce, hesap, gönül gibi soyut kavramların yer- yön metaforları şeklinde kavramsallaştırıldığı görülmektedir. Kutadgu Bilig'deki yönelim metaforlarından hareketle her aşağı yönelimin olumsuzluğu ifade etmediği görülmüştür. Örneğin batıg saḳış (derin hesap), ḳılḳı alçak, köyli ḳoḍḳ (alçak gönüllü olma) ifadeleri aşağı yönelim göstermesine rağmen olumlu bir anlam barındirmaktadır.

Kültürel metaforlarda önemli bir nokta öncelikle köklerini dünya görüşü, sosyal ve kültürel durumlardan aldığıdır. Bu metaforlar kültürel kavramlaştırmalarda önemli bir yerdedir. Kaynak ve Hedef alanlarının oluşturduğu haritalama kültürel metaforların oluşturulmasında önemli bir noktadır. Kaynak alan köklerini toplumsal, somut ve kişi yaşantılarından alır. Bu konuda belirleyici nokta kaynak alan ve içeriğidir. Kavramsal olan kültürel metaforların oluşumu bilişsel özelliklere dayanır. Aktardığı düşünce ve kullanıldığı bağlam aracılığı ile kavramsal olan bu metaforlar kültürel metafor özelliği kazanır. Metin içerisindeki sistemli kullanımları, tarih boyunca sürekliliği ve miras olarak günümüzde yaşamaları kültürel metaforları biliş ve düşünce açısından güçlü kılmaktadır.

\section{Yazar Notu:}

Bu makale çalışması hala devam eden "Kutadgu Bilig Metaforları" adlı doktora tezinden üretilmiştir. 


\section{KAYNAKÇA}

Adalı O. (1982). Yüksek Öğrenimde Sözlü ve Yazılı Anlatım. İzmir 1982.

Aksan D. (1978). Anlambilimi ve Türk Anlambilimi. Ankara 1978.

Aksan D. (1990). Her Yönüyle Dil- Ana Çizgileriyle Dil Bilim III. Ankara 1990.

Aksan D. (1998). Anlam Bilim Konuları ve Türkçenin Anlambilimi. Ankara 1998.

Aksan D. (2015). Türkçeye Yansıyan Türk Kültürü. Ankara 2015.

Amirova N. D. (2014). “Dilbilimde Özgün Bir Yaklaşım: Kültür Dil Bilim”. Çev. Ü. Dohman, Ed. O. Kozan, Kültür Dil Bilim Temel Kavramlar ve Sorunlar. Ankara (2014) 24-28.

Bayat F. (2015). Türk Mitolojik Sistemi Ontolojik ve Epistemolojik Bağlamda Türk Mitolojisi. İstanbul 2015. Erdem M. (2003). Türkmen Türkçesinde Metaforlar. Ankara 2003.

Erdem M. (2007). "Kültürel Dilbilimi ve Türkmen Türkçesinde Deyim Aktarmaları (Metaphor) Üzerine". IV. Uluslararası Türk Dili Kurultayı Bildirileri (24- 29 Eylül 2000). Cilt I (2000) 539- 550.

Ervas F. \& Gola E. (2013). "The Pragmatics of Metaphor Use, from the Conceptual View to the Relevance-The Arctic Perspective”. Eds. E. Gola \& F. Ervas, Metaphor in Focus, Philosophical Perspectives on Metaphor Use. London (2013) 21-34.

Günay V. D. (2016). Kültürbilime Giriş, -Dil, Kültür ve Ötesi. İstanbul 2016.

Güvenç B. (1995). Türk Kimliği Kültür Tarihinin Kaynakları. Ankara 1995.

Holland D. \& Quinn N. (1989). “Culture and Cognition. Eds. Dorothy Holland- Naomi Quinn”. Cultural Maodels in Language and Though (1989) 3-40.

Kaplan M. (1983). Kültür ve Dil. İstanbul 1983.

Kemal M. (2003). Buddhist Türk Çevresi Eserlerinde Metafor. Yayımlanmış Doktora Tezi. Ankara Üniversitesi, Ankara 2003.

Kozan O. (2014). Kültürdilbilim Temel Kavramlar ve Sorunlar. Ankara 2014.

Kövecses Z. (2005). Metaphor in Culture Universality and Variation. London 2005.

Kövecses Z. (2009). Metaphor: A Practical Introduction, London 2009.

Kövecses Z. (2017). "Context in Cultural Linguistics: The Case of Metaphor”. Ed. F. Sharifian, Advances in Cultural Linguistics, Cultural Linguistics. Singapore (2017) 307- 323.

Kula O. B. (2012). Dil Felsefesi Edebiyat Kuramı. 2 cilt. İstanbul 2012.

Lakoff G. \& Johnson M. (1980). Metaphors We Live By. Chicago 1980.

Lakoff G. \& Johnson M. (1999). Philosophy in the Flesh, the Embodied Mind and it's Challenge to Western Thought. New York 1999.

Sharifian F. (2001). "I. Association- Interpretation: A Research Technique in Cultural and Cognitive Linguistics". Proceedings the 6th Annual Round Table of the Centre for Applied Language and Literacy Research (2001). Australia. Kaynak: https://www.academia.edu/1320290/Association Interpretation_A_research_technique_in_cultural_and_cognitive_linguistics

Sharifian F. (2012). "Linguistic Theory and Cultural Conceptualisations". Journal of Language, Culture and Translation (LCT) 1/3 (2012) 93-110.

Sharifian F. (2015). "Cultural Linguistics and World Englishes". World Englishes WE (2015) 1-18.

Sharifian F. (2017). Cultural Linguistics. Amsterdam 2017.

Tanpınar A. H. (1977). Edebiyat Üzerine Makaleler. İstanbul 1977.

Üstünel-Yaylagül Ö. (2018). "Menâkıb u Tevârih-i Âl-i Osman'daki Ölüm Kavramsal Alanıyla İlgili Sözler ve Uygulamalar”. Gazi Türkiyat Araştırmaları Dergisi 22 (2018) 9- 27.

Yaylagül-Üstünel Ö. (2015). “Kutadgu Bilig'deki Bazı Metaforlar Üzerine”. Modern Türklük Araştırmaları Dergisi 12/4 (2015) 39-53.

Yaylagül-Üstünel Ö. (2016). "Kutadgu Bilig'deki Düşünce Aktarımı”. Modern Türklük Araştırmaları Dergisi 13/4 (2016) 166-178.

Yunusoğlu M. K. (2016). Budist Türk çevresi Eserlerde Metaforlar. Ankara 2016. 